\title{
BRPKM
}

Buletin Riset Psikologi dan Kesehatan Mental

http://e-journal.unair.ac.id/index.php/BRPKM

e-ISSN: 2776-1851

ARTIKEL PENELITIAN

\section{Hubungan antara Harga Diri dengan Penerimaan Kekerasan dalam Pacaran pada Perempuan Dewasa Muda}

\author{
MAHARANI DEWI \& NURUL HARTINI* \\ Fakultas Psikologi Universitas Airlangga
}

\begin{abstract}
ABSTRAK
Penelitian ini bertujuan untuk mengetahui hubungan antara harga diri dengan penerimaan kekerasan dalam pacaran pada perempuan dewasa muda. Penelitian ini merupakan penelitian kuantitatif dengan 75 partisipan perempuan dewasa muda di wilayah Indonesia. Alat ukur yang digunakan dalam penelitian ini adalah skala harga diri dengan reliabilitas sebesar $\alpha=0,860$ dan skala penerimaan kekerasan dalam pacaran dengan reliabilitas sebesar $\alpha=0,527$. Hasil uji hipotesis $(r(75)=-0,099$; $\rho=0,399$ ) menunjukkan tidak terdapat hubungan antara harga diri dengan penerimaan kekerasan dalam pacaran pada perempuan dewasa muda dengan korelasi yang sangat lemah dan negatif.
\end{abstract}

Kata kunci: harga diri, penerimaan kekerasan, perempuan

\section{ABSTRACT}

This study aims to determine the relationship between self-esteem and acceptance of dating violence in young adult women. This study is a quantitative study with 75 young adult female participants in the territory of Indonesia. The measuring instrument used in this study is a self-esteem scale with a reliability of $=0.860$ and a scale of acceptance of dating violence with a reliability of $=0,527$. The results of hypothesis testing $(\mathrm{r}(75)=-0,099 ;=0,399)$ showed that there was no relationship between selfesteem and acceptance of dating violence in young adult women with a very weak and negative correlation.

Keywords: acceptance of violence, self-esteem, women

Buletin Penelitian Psikologi dan Kesehatan Mental (BRPKM), 2021, Vol. 1(1), 947-955

*Alamat korespondensi: Fakultas Psikologi Universitas Airlangga, Kampus B Universitas Airlangga Jalan

Airlangga 4-6 Surabaya 60286. Pos-el: nurul.hartini@psikologi.unair.ac.id

Naskah ini merupakan naskah dengan akses terbuka dibawah ketentuan the Creative

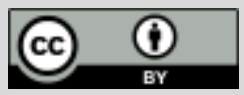
Common Attribution License (CC-BY-4.0) (http://creativecommons.org/licenses/by/4.0), sehingga penggunaan, distribusi, reproduksi dalam media apapun atas artikel ini tidak dibatasi, selama sumber aslinya disitir dengan baik. 


\section{P E N D A H U L U A N}

Tahap perkembangan pada dewasa muda dihubungkan dengan masalah penentuan pasangan, pernikahan, dan juga tahap membangun sebuah keluarga (Hafighurst, 1955). Dewasa muda perlu menjalin suatu hubungan yang lebih dari pertemanan, di Indonesia, hal ini dikenal dengan istilah pacaran (Sholikhah \& Masykur, 2020). Pacaran ialah sebuah proses yang dialami seseorang untuk bertemu dengan seseorang lainnya untuk masuk ke dalam konteks sosial (Straus, 2004). Tujuannya adalah mencoba kemungkinan apakah sesuai atau tidak untuk seseorang tersebut dijadikan pasangan hidup (Ghaida, 2017). Manfaat pacaran ialah memahami kemampuan secara sosial, memahami diri sendiri serta orang lain, kesempatan untuk memahami tentang peran jenis, dan berbagai cara yang bisa dilakukan dalam mengatasi permasalahan (Landis \& Landis, 1963).

Relasi yang dekat antar individu satu dengan individu lainnya dalam konteks hubungan pacaran ini tidak mungkin terhindar dari suatu konflik. Apabila konflik tidak bisa diselesaikan secara baik oleh suatu pasangan, hal tersebut bisa memunculkan suatu perilaku yang disebut kekerasan. Kekerasan dalam pacaran ialah suatu penggunaan dengan taktik kekerasan dan juga tekanan fisik agar mendapatkan maupun mempertahankan suatu kekuasaan ataupun kontrol terhadap pasangannya (Murray, 2007). Kekerasan dibagi menjadi beberapa jenis, yaitu secara fisik, seksual, emosional/psikis, dan lain-lain (Mardiah dkk., 2017). Suatu kekerasan sering terjadi dalam hubungan pacaran (Straus, 2004)

Hubungan pacaran sehat memiliki makna apabila keduanya bisa menjaga keutuhan masing-masing. saling menghargai dan menjaga perasaan satu sama lain. Apabila terdapat suatu konflik, maka penyelesaiannya harus dilakukan dengan baik sebagaimana sejalan dengan manfaat pacaran, yaitu belajar tentang cara-cara yang biasa dilakukan dalam mengatasi permasalahan. Sejalan dengan penelitian (Nisa, 2008) jika dua orang sedang menjalani hubungan berpacaran dan dihadapkan dengan suatu konflik, maka jalan untuk menyelesaikannya ialah dengan pengendalian diri diantaranya. Namun kenyataannya banyak pasangan yang tidak bisa menyelesaikan konflik dengan baik dan berakhir dengan kekerasan. Mirisnya, banyak perempuan yang justru menerima perilaku kekerasan dari pasangannya.

Fenomena dan juga kasus kekerasan dalam pacaran ini erat kaitannya dengan penerimaan kekerasan dalam pacaran, yang merupakan suatu sikap penerimaan pada suatu perbuatan kekerasan yang dilakukan pasangan (Schnurr dkk., 2010). Menerima kekerasan yang dilakukan pasangan adalah hal buruk dalam hidup, yang mana menjadikan hidup seseorang bimbang antara melepaskan pasangannya atau menerima hubungan tersebut yang disertai tindakan kekerasan. Penerimaan kekerasan ini muncul karena korban menganggap bahwa hal tersebut biasa terjadi dalam suatu hubungan dan mungkin mereka bisa jadi merasa pantas untuk diperlakukan seperti itu karena merupakan bukti dari tanda cinta pasangan terhadap korban (Violence Prevention, 2017). Hasil penelitian yang dilakukan Putriana (2018) mengatakan bahwa perempuan akan melepaskan pasangannya jika ia merasakan penat yang sudah berlebih, dan tidak ingin jika terus menerus dikelilingi dengan kekerasan. Sebagian perempuan memilih untuk bertahan dengan pasangan dengan alasan menunjukkan strategi coping yang baik. Tetapi, pilihan untuk bertahan dengan pasangan juga hal yang cukup sulit, dan memunculkan suatu risiko. Mempertahankan hubungan yang diselingi dengan tindakan kekerasan tidak hanya mempengaruhi kesehatan secara fisik.

Sekitar 50\% korban kekerasan memilih untuk bertahan dan melanjutkan hubungan. Dari jumlah keseluruhan korban yang memilih untuk melanjutkan hubungan, sekitar $60 \%$ korban mengatakan tidak ada perubahan atau peningkatan perilaku dari pelaku kekerasan (Bethke \& Dejoy, 1993). Dari penelitian 
ini, menunjukkan bahwa tidak semua korban penerimaan kekerasan akan mengalami perubahan dalam menjalani suatu hubungan romantisme dengan pelaku kekerasan. Korban yang merasakan kekerasan ini merupakan suatu hal yang memiliki dampak buruk, namun terdapat pertimbangan lain seperti tetap berpikir positif dan masih bersama dengan pelaku, maka akan memunculkan suatu perasaan tertekan dan kemungkinan tidak menikmati hubungan romantisme. Sedangkan korban yang merasa kekerasan yang terjadi merupakan suatu hal yang biasa dan juga ungkapan cinta, maka penerimaan nya menjadi lebih besar, hal tersebut tidak berdampak negatif bagi kehidupannya karena ia menikmati hubungan romantismenya meskipun diiringi dengan tindakan kekerasan.

Korban mengatakan bahwa kekerasan adalah pilihan pasangan untuk membuktikan kasih dan sayang, perempuan tersebut merasa bahwa hal tersebut tidak terlalu buruk. Korban juga memilih untuk bertahan karena menganggap dirinya yang mampu memahami dan melindungi, sehingga korban mendapat harapan bahwasanya ada perubahan yang terjadi pada perlakuan pasangan. Sehingga korban tetap menyikapi dengan baik serta menaruh perhatian dan kasih sayang yang begitu besar terhadap pelaku kekerasan (Sekarline \& Margaretha, 2013). Dewasa awal yang melakukan penerimaan kekerasan dalam pacaran semestinya sudah memiliki pemikiran secara logis mengenai hubungan yang tidak sehat serta dampaknya untuk diri sendiri (Santrock, 2011). Pada dewasa awal, dari segi kognitif sudah lebih matang, namun memiliki banyak pertimbangan untuk mengakhiri hubungan seperti suatu komitmen, perasaan malu dengan keluarga dan rekan, serta perasaan maklum, dan berharap pasangan akan mengalami perubahan seiring berjalannya waktu agar tetap bisa mencapai ke jenjang hubungan yang lebih serius (Clinical Psychologist, 2003). Faktor-faktor yang mempengaruhi munculnya penerimaan kekerasan dalam pacaran, diantaranya perasaan tidak berdaya, afeksi yang membelenggu, menerima peran otoritas, harapan terhadap figur pelindung, keterbatasan dalam memahami dan menyelesaikan suatu masalah, serta kurangnya pemahaman tentang kekerasan (Segaf dkk., 2009).

Komisioner Komnas Perempuan, Sri Nurherwati menjelaskan bahwa perempuan sering berada pada posisi yang lemah dikarenakan hukum di Indonesia belum bisa melindungi hak seorang perempuan (Noerdin dkk., 2006). Kesimpulannya adalah adanya kekurangan pada dukungan dan juga hukum yang berlaku di Indonesia menjadi faktor penyebab dari munculnya penerimaan kekerasan pada perempuan. Teori feminis mengatakan bahwa penerimaan kekerasan yang terjadi pada perempuan adalah hal yang sulit dihindari dari sistem masyarakat patriarki, yang mana secara langsung memperbolehkan laki-laki untuk lebih unggul dan mengatur pasangannya (Scott \& Straus, 2007). Norma budaya yang membantu pernyataan bahwa kekerasan adalah sesuatu yang biasa dan dianggap sebagai cara menyelesaikan masalah. Kekuasaan yang dimiliki perempuan jauh lebih kecil jika dibandingkan laki-laki, sehingga perempuan sering menjadi korban kekerasan domestik, terutama dalam hubungan pacaran (Sunarto, 2004).

Penerimaan kekerasan yang dilakukan perempuan timbul karena terbatasnya dukungan masyarakat dan hukum yang berlaku, serta keyakinan perempuan terhadap kekerasan (Putri, 2012). Perempuan mengatakan bahwa penerimaan kekerasan yang dilakukan adalah sebagai bentuk ketaatan pada pasangannya, dengan percaya bahwa perlakuan pasangannya dapat beralih menjadi baik, dan juga terbatasnya dukungan yang dimiliki baik secara sosial maupun individu (Arivia, 2002). Selain itu menurut penelitian Poerwandari (2008) bahwa timbulnya ketidaksetaraan gender membuat perempuan berada sebagai orang yang lemah, korban dari pasangan yang dianggap lebih mempunyai dominan. Pada penelitian (Mahase, 2019) menyatakan bahwa perempuan yang melakukan penerimaan kekerasan secara terus menerus mempunyai konsekuensi dua kali lipat untuk sikap kecemasan dan konsekuensi tiga kali lipat menimbulkan penyakit psikis terlebih kondisi yang parah seperti skizofrenia 
serta gangguan lainnya. Perempuan yang melakukan penerimaan kekerasan dalam pacarannya memiliki karakteristik harga diri yang rendah (Putri, 2012).

Harga diri pada sebagian penelitian dilihat sebagai sesuatu yang berbeda-beda, ada yang menganggap bahwa harga diri sebagai dampak, dan ada yang menyebut harga diri menjadi faktor. Perbedaan ini terjadi karena adanya perbedaan harga diri sebagai hal yang berubah-ubah atau malah tetap dalam diri seseorang (Holt, 2007). Pada penelitian Israr (2008) mengatakan bahwa perempuan dengan harga diri yang rendah cenderung menyalahkan diri (tidak berani menolak), menutup diri, dan menganggap bahwa dirinya tidak berharga. Perempuan dengan harga diri rendah tidak mampu mengungkap pikiran dan perasaannya akan hal yang terjadi pada dirinya. Hal ini menjadi penguat akan penerimaan kekerasan dalam hubungan berpacarannya. Selanjutnya, pada penelitian yang dilakukan oleh Sherer (2009) mengatakan bahwa perempuan yang memiliki harga diri rendah tidak mempunyai kepercayaan bahwa diri sendiri sama dengan laki-laki, tidak menilai dirinya adalah seseorang yang berharga, dan memiliki keahlian yang sama dengan laki-laki. Perempuan yang harga dirinya rendah lebih menerima tindakan kekuasaan dari pasangannya, dan hal ini memiliki dampak yang buruk pada perempuan tersebut, seperti merasa tidak memiliki kemampuan serta tidak kuat, hal ini membuat penerimaan kekerasan terus terjadi.

Berdasarkan paparan di atas, diketahui bahwa perbedaan hasil yang telah dilakukan oleh penelitianpenelitian sebelumnya mendorong penelitian ini untuk dilakukan, namun lebih mendalami pada variabel penerimaan kekerasan dalam pacaran, yaitu menguji hubungan antara harga diri dan penerimaan kekerasan dalam pacaran. Hal ini dimaksudkan untuk mengetahui apakah ada hubungan antara harga diri dengan penerimaan kekerasan dalam pacaran pada perempuan dewasa muda.

\section{E T O D E}

\section{Desain Penelitian}

Penelitian ini menggunakan desain penelitian dengan jenis survei, yaitu penelitian yang dilakukan tanpa memanipulasi situasi dan kondisi. Penelitian teknik survei ini mengikutsertakan orang-orang untuk mengisi kuisioner (Neuman, 2007). Hal ini sejalan dengan tujuan penelitian, yaitu untuk mengetahui hubungan antar kedua variabel, yakni variabel harga diri dan variabel penerimaan kekerasan dalam pacaran.

\section{Partisipan}

Partisipan dalam penelitian ini adalah perempuan dewasa muda berusia 18-25 tahun, pernah atau sedang berpacaran dan menjadi korban kekerasan pacaran baik kekerasan fisik, seksual, maupun psikis yang berada di wilayah Indonesia. Secara keseluruhan jumlah partisipan dalam penelitian ini adalah 200 orang, namun yang memenuhi kriteria hanya 75 orang $(\mathrm{N}=75,37,5 \%$ perempuan). Penentuan partisipan dilakukan dengan menggunakan teknik nonprobability jenis purposive sampling.

\section{Pengukuran}

Harga diri ialah suatu pandangan positif atau negatif seseorang terhadap dirinya sendiri atau dapat dikatakan suatu evaluasi menyeluruh tentang bagaimana seseorang menilai dirinya (Rosenberg, 1965). 
Pengukuran harga diri menggunakan alat ukur Rosenberg self-esteem scale yang dikonstruksi oleh (Rosenberg, 1965) dengan total 10 aitem yang mana telah diterjemahkan ke Bahasa Indonesia pada penelitian yang dilakukan oleh Hanani (2019) melalui artikel jurnal yang berjudul "Pengaruh self-esteem terhadap Resiliensi pada Mahasiswa Tahun Pertama Program Studi Kedokteran" dan diterbitkan oleh Fakultas Psikologi Universitas Negeri di Kota Jakarta. Rating alat ukur tersebut menggunakan skala Guttman dengan empat pilihan jawaban dengan reliabilitas sebesar $\alpha=0,860$.

Penerimaan kekerasan dalam pacaran merupakan suatu sikap penerimaan pada perbuatan kekerasan yang dilakukan oleh pasangan (Schnurr dkk., 2010). Pengukuran penerimaan kekerasan dalam pacaran menggunakan alat ukur The Acceptance of Dating Violence scale (ADV) versi Bahasa Indonesia yang telah ditranslasi oleh peneliti dari alat ukur asli yaitu The Acceptance of Dating Violence scale (ADV): Psychometric Properties of the Spanish Version yang dikonstruksi oleh Gonzales dkk. (2017). Alat ukur tersebut terdiri dari 10 aitem. Rating alat ukur tersebut menggunakan skala Likert dengan enam pilihan jawaban, dengan reliabilitas sebesar $\alpha=0,527$.

\section{Analisis Data}

Teknik analisis data yang digunakan dalam penelitian ini adalah teknik spearman's rho. Teknik analisis ini dilakukan setelah mengetahui bahwa data penelitian ini berdistribusi tidak normal yang dilakukan dengan uji normalitas Kolmogorov Smirnov. Perangkat lunak yang digunakan untuk menganalisa data dalam penelitian adalah SPSS 22 for Windows.

\section{HAS I L P EN ELITIA N}

Penelitian ini memiliki hasil yang didapatkan bahwa nilai pada variabel harga diri $(M=23,16, N=75)$ dengan kategori harga diri tingkat rendah. Sedangkan untuk variabel penerimaan kekerasan dalam pacaran didapatkan nilai $(M=22,28, N=75)$ dengan kategori penerimaan kekerasan dalam pacaran tingkat tinggi.

Berdasarkan hasil uji asumsi, data berdistribusi tidak normal $(\rho=0,000)$, dan kedua variabel tidak memiliki korelasi serta berada pada tingkat sangat lemah dan negatif $(r(75)=-0,099 ; \rho=0,399)$.

\section{I S K U S I}

Berdasarkan analisis data, bahwa tidak adanya hubungan yang signifikan antara harga diri dengan penerimaan kekerasan dalam pacaran pada perempuan dewasa muda. Hubungan yang terdapat pada kedua variabel penelitian tersebut berada pada tingkat sangat lemah dan negatif. Hasil penelitian ini sejalan dengan penelitian oleh Putri (2012) yang menunjukkan bahwa hubungan antara keduanya negatif, dimana meningkatnya frekuensi penerimaan kekerasan yang dialami oleh perempuan dewasa muda diikuti dengan menurunnya harga diri pada perempuan.

Penelitian lainnya yang mendukung adalah penelitian yang dilakukan oleh Israr (2008) yang mengatakan bahwa perempuan dengan harga diri yang rendah cenderung menyalahkan diri (tidak berani menolak), menutup diri, dan menganggap bahwa dirinya tidak berharga. Perempuan dengan harga diri rendah tidak mampu mengungkap pikiran dan perasaannya akan hal yang terjadi pada dirinya. Hal ini menjadi penguat akan penerimaan kekerasan dalam hubungan berpacarannya. Selanjutnya, pada penelitian oleh Sherer (2009) yang mengatakan bahwa perempuan yang memiliki harga diri rendah tidak mempunyai kepercayaan bahwa diri mereka sama dengan pihak laki-laki, tidak melihat bahwa dirinya individu yang berharga, dan mempunyai keahlian yang sama dengan laki-laki. 
Perempuan yang harga dirinya rendah bisa lebih menerima tindakan kekuasaan dari pasangannya, dan hal ini berdampak pada negatif pada kehidupan perempuan tersebut, seperti merasa tidak berdaya dan lemah, sehingga hal inilah yang membuat penerimaan kekerasan terus terjadi. Meningkatnya harga diri perempuan dapat membatasi penerimaan kekerasan yang terjadi dalam pacaran.

Selain itu, terdapat berbagai pendapat masyarakat Indonesia mengenai perempuan yang melakukan penerimaan kekerasan. Komisioner Komnas Perempuan, Sri Nurherwati menjelaskan bahwa perempuan sering berada pada posisi orang yang lemah karena aturan di Indonesia belum bisa menaungi perempuan (Noerdin dkk., 2006). Kesimpulannya adalah keterbatasan dukungan dan hukum yang terjadi di Indonesia menjadi faktor munculnya penerimaan kekerasan pada perempuan. Kekuasaan yang dimiliki perempuan jauh lebih kecil jika dibandingkan laki-laki, sehingga perempuan seringkali menjadi korban kekerasan domestik, maupun kekerasan dalam pacaran (Sunarto, 2004). Perempuan mengatakan bahwa penerimaan kekerasan yang dilakukan adalah sebagai bentuk ketaatan terhadap pasangannya, dengan kepercayaan bahwa pasangannya dapat berubah, dan juga terbatasnya dukungan yang dimiliki baik secara sosial maupun individu (Arivia, 2002). Selain itu menurut penelitian oleh Poerwandari (2008) terdapat ketidaksetaraan gender membuat perempuan berada sebagai orang yang lemah, korban dari pihak laki-laki yang diyakini lebih mempunyai dominan.

Terdapat juga teori feminis yang mengatakan bahwa penerimaan kekerasan yang terjadi pada perempuan adalah hal yang sulit dihindari dari golongan masyarakat patriari, yang mana memberi ruang pada laki-laki untuk lebih menguasai dan mengatur pasangannya (Scott \& Straus, 2007). Norma budaya yang menunjang pernyataan kekerasan adalah hal yang lumrah dan dianggap sebagai cara menyelesaikan permasalahan.

Menurut pernyataan yang dikemukakan oleh Michener \& DeLamater (1999) bahwa seseorang dengan harga diri yang tinggi bisa menyatakan diri secara baik, sehingga pengungkapan diri yang timbul bukan sebagai penutup kekurangannya. Hal ini mungkin adanya faktor-faktor yang mempengaruhi tingkat harga diri tersebut, seperti yang dikemukakan oleh Rusli (2003) bahwa faktor dari terbentuknya harga diri ialah keluarga, lingkungan, pencapaian prestasi, dan diri sendiri. Hal ini sejalan dengan penelitian Chung (2007) yang mana hasil penelitiannya menyatakan bahwa perempuan yang menjadi penerima kekerasan dalam berpacaran harus memiliki dukungan yang berasal dari kerabat maupun teman, agar korban merasa bahwa lingkungan terdekatnya mendukung dalam meningkatkan harga diri untuk menjalani hubungan yang lebih baik kedepannya.

Faktor-faktor lain yang mempengaruhi munculnya penerimaan kekerasan dalam pacaran, yaitu rasa tidak berdaya, afeksi yang membelenggu, menerima akan peran otoritas, harapan terhadap sosok pengayom, terbatas dalam hal menyelesaikan masalah, serta terbatasnya pengetahuan tentang kekerasan (Segaf dkk., 2009). Hal ini sejalan dengan penelitian Sekarlina (2013) mengatakan bahwa ikatan yang kuat antara korban dan pelaku seperti perasaan kasih sayang, cinta terhadap pelaku dan hal ini masuk ke dalam salah satu faktor yaitu afeksi yang membelenggu, lalu melindungi pelaku kekerasan, menyalahkan diri sendiri sebagai penyebab kekerasan, dan menyangkal bahwa kekerasan yang terjadi tidak terlalu buruk menjadikan penerimaan kekerasan dalam berpacaran muncul dalam diri korban kekerasan.

Penelitian ini tidak luput dari kekurangan. Penelitian ini memiliki keterbatasan selama proses pelaksanaannya. Dalam penentuan sampel dalam penelitian ini ditentukan dengan berdasar pada buku Azwar (2018) bahwa pada umumnya sampel penelitian berjumlah minimal 30 partisipan dan kurang dari 500 partisipan. Penentuan ini dikarenakan terbatasnya penelitian-penelitian terdahulu mengenai kedua variabel yang telah ditentukan, sehingga untuk menentukan sampel menggunakan nilai effect size 
tidak dapat dilakukan. Setelah dilakukan penentuan sampel, peneliti memperoleh sampel dan sampel yang digunakan sebanyak 75 partisipan, yang mana angka tersebut sudah cukup untuk digunakan dalam penelitian. Selanjutnya, referensi penelitian untuk variabel penerimaan kekerasan dalam pacaran masih kurang dan belum ada pembaruan penelitian dengan tema kedua variabel tersebut.

\section{S I M P U L A N}

Berdasarkan hasil penelitian, dapat diketahui bahwa perempuan dewasa muda berada pada harga diri yang tergolong rendah dan juga penerimaan kekerasan dalam pacaran yang tergolong tinggi. Selain itu, dapat disimpulkan pula bahwa tidak terdapat hubungan antara variabel harga diri dengan variabel penerimaan kekerasan dalam pacaran pada perempuan dewasa muda. Hubungan yang dihasilkan variabel harga diri dengan variabel penerimaan kekerasan dalam pacaran bersifat negatif yang artinya semakin meningkat harga diri yang dimiliki perempuan dewasa muda ,maka penerimaan kekerasan dalam pacaran cenderung rendah. Sebaliknya, jika semakin rendah harga diri yang dimiliki perempuan tersebut, maka penerimaan kekerasan dalam pacaran cenderung meningkat. Sehingga bagi perempuan dewasa muda, khususnya yang sedang atau pernah berada dalam hubungan, diharapkan untuk lebih bisa meningkatkan harga diri agar tidak mudah menerima kekerasan yang sewaktu-waktu dapat terjadi di hubungan tersebut. Penelitian ini terdapat kekurangan, sehingga untuk penelitian selanjutnya bisa meneliti faktor-faktor lain yang memunculkan penerimaan kekerasan dalam berpacaran di Indonesia, dikarenakan faktor harga diri bukan lah satu-satunya faktor yang dapat mempengaruhi penerimaan kekerasan dalam pacaran.

\section{U C A P A N T ER I MAKASIH}

Penulis mengucapkan terima kasih kepada pihak-pihak yang berkontribusi dalam proses penelitian terutama kepada partisipan penelitian yang telah meluangkan waktu di sela-sela kesibukan sehingga penelitian ini dapat diselesaikan dan diharapkan dapat memberi kontribusi baik bidang akademik maupun praktis.

\section{DEKLARASI POTENSI TERJADINYA KONFLIK KEPENTINGAN}

Maharani Dewi dan Nurul Hartini tidak bekerja, menjadi konsultan, memiliki saham, atau menerima dana dari perusahaan atau organisasi mana pun yang akan mengambil untung dari naskah ini, dan telah mengungkapkan bahwa ia tidak memiliki afiliasi selain yang telah disebut di atas.

\section{PUSTAKA ACUAN}

Arivia, G. (2002). Hentikan Kekerasan terhadap Perempuan. Yayasan Jurnal Perempuan.

Azwar, S. (2018). Metode Penelitian Psikologi. Pustaka Belajar.

Bethke, T. M., \& Dejoy, D. M. (1993). An Experimental Study of Factors Influencing the Acceptability of Dating Violance. Jurnal of Interpersonal Violance, 8(1), 36-51. 
Clinical Psychologist, Joseph M Carver, Ph.D (2003). : http://drjoecarver.makeswebsites.com/clients/ 49355/File/love_and_stockholm_syndrome.html

Chung, D. (2007). Making meaning of relationship: Young women's experiences and understandings of dating violence. Journal of Violence Against Women, 1274-1295.

Ghaida, Z. P., M. Y. (2017). Hubungan antara Kekerasan dalam Berpacaran (Dating Violence) dengan Self Esteem pada Wanita Korban KDP di Kota Bandung. Prosiding Psikologi, 303-309.

Gonzales, L. F., Esther, C., \& Izaskun, 0. (2017). The Acceptance of Dating Violence Scale (ADV): Psychometric Properties of The Spanish Version. Psychotema, 241-246.

Hafighurst. (1955). Human Development and Education. Longman, Green and Co.

Hanani, C. A. (2019). Pengaruh Self Esteem terhadap Resiliensi pada Mahasiswa Tahun Pertama Program Studi Kedokteran [Jurnal Publikasi]. Negeri Jakarta.

Holt, J. L. (2007). Impact of Self-Esteem, Adult Attachment, and Family on Conflict Resolution in Intimate Relationships.

Israr, Y. A. (2008). Peranan forensik klinik dalam kasus kekerasan terhadap anak dan perempuan. Forensik Klinik.

Landis, J. T., \& Landis, M. G. (1963). Building a Successul Marriage 4th edition: Englewood Cliffs. Prentice Hall Inc.

Mahase, E. (2019). Women Who Experience Domestic Abuse are Three Times as Likely to Develop Mental Ilness. The BMJ.

Mardiah, A., Satriana, D. P., \& Syahriati, E. (2017). Peranan Dukungan Sosial dalam Mencegah Kekerasan dalam Pacaran: Studi Korelasi pada Remaja di Jakarta. Jurnal Psikologi Ulayat: Indonesian Journal of Indigenous Psychology, 4(1), 29-42.

Michener, H. A., \& DeLamater, J. D. (1999). Social Psychology (Fourth). Harcourt Brace Collage Publishers.

Murray, J. (2007). But I Love Him: Protecting Your Daughter from Controlling, Abusive Dating Relationship. Harper Collins Publisher.

Neuman, W. L. (2007). Basics of Social Research Methods: Qualitative and Quantitative Approaches (Fourth). Allyn and Bacon.

Nisa, S. (2008). Konflik Pacaran Jarak Jauh Dewasa Muda [Skripsi]. Gunadarma Fakultas Psikologi.

Noerdin, E., Agustini, E., Pakasi, D. T., Aripurnami, S., \& Hodijah, S. N. (2006). Potret Kemiskinan Perempuan. Women Research Institute. 
Poerwandari, E. K. (2008). Penguatan psikologis untuk menanggulangi kekerasan dalam rumah tangga dan kekerasan seksual: Panduan dalam bentuk tanya jawab. Program Studi Kajian Wanita Universitas Indonesia.

Putri. (2012). Hubungan antara Kekerasan dalam Pacaran dan Self Esteem pada Perempuan Dewasa Muda [Jurnal Publikasi].

Putriana, A. (2018). Kecemasan dan Strategi Coping pada Wanita Korban Kekerasan dalam Pacaran (Studi Kasus di Samarinda). Psikoborneo, 691-703.

Rosenberg, M. (1965). Society and the adolescent self-image. Princeton University Press.

Rusli, L. (2003). Self Esteem: Landasan Kepribadian. Bagian Proyek Peningkatan Mutu Organisasi dan Tenaga Keolahragaan Dirjen Olahraga Depdiknas.

Santrock. (2011). Perkembangan Anak (7 ed., Vol. 2). Erlangga.

Schnurr, M. P., Lohman, B. J., \& Kaura, S. A. (2010). Variation in Late Adolescents' Reports of Dating Violence Perpetration: A Dyadic Analysis. Violence and Victims, 25(1), 84-99.

Scott, K., \& Straus, M. (2007). Denial, minimization, partner blamming, and intimate aggression in dating partners. Journal of Interpersonal Violence, 851-871.

Segaf, Z., Yumpi, F., \& Kursistin, P. (2009). Memahami Perempuan Bertahan dalam Kekerasan Domestik. $1-17$.

Sekarlina, I. (2013). Stockholm syndrome pada wanita dewasa awal yang bertahan dalam hubungan yang penuh kekerasan [Skripsi]. Airlangga.

Sekarline, I., \& Margaretha. (2013). Stockholm Syndrome pada Wanita Dewasa Awal yang Bertahan dalam Hubungan yang Penuh Kekerasan. Jurnal Psikologi Klinis dan Kesehatan Mental, 1-6.

Sherer, M. (2009). The nature and correlates of dating violence among jewish and arab youths in israel. Journal Family Violence, 11-26.

Sholikhah, R. S., \& Masykur, A. M. (2020). “Atas Nama Cinta, Ku Rela Terluka” (Studi Fenomenologi pada Perempuan Korban Kekerasan dalam Pacaran). Empati, 8(4), 52-62.

Straus, M. A. (2004). Prevalence of Violence Against Dating Partners by Male and Female University Students Worldwide. Violence against women, 10(7), 790-811.

Sunarto. (2004). Pengantar Sosiologi. Lembaga Penerbit Fakultas Ekonomi.

Violence Prevention, National Center for Injury Prevention and Control Division of Violence Prevention (2017). https://www.cdc.gov/violenceprevention/pdf/tdv-factsheet.pdf 